\title{
Response of Winter Wheat Grain Yield and Phosphorus Uptake to Foliar Phosphite Fertilization
}

\author{
Muaid S. Ali, ${ }^{1}$ Apurba Sutradhar, ${ }^{2}$ Ma Lourdes Edano, ${ }^{2}$ \\ Jeffrey T. Edwards, ${ }^{2}$ and Kefyalew Girma ${ }^{3}$ \\ ${ }^{1}$ Marshes Research Center, Thi-Qar University, Al-Nasiriyah, Thi-Qar, Iraq \\ ${ }^{2}$ Department of Plant and Soil Sciences, Oklahoma State University, Stillwater, OK 74078, USA \\ ${ }^{3}$ Department of Crop and Soil Sciences, Washington State University, Prosser, WA 99350, USA
}

Correspondence should be addressed to Kefyalew Girma; kefyalew.desta@wsu.edu

Received 26 September 2013; Revised 13 March 2014; Accepted 18 March 2014; Published 8 May 2014

Academic Editor: Robert J. Kremer

Copyright (C) 2014 Muaid S. Ali et al. This is an open access article distributed under the Creative Commons Attribution License, which permits unrestricted use, distribution, and reproduction in any medium, provided the original work is properly cited.

\begin{abstract}
One of the major problems that potentially hinders the use of foliar fertilization as a tool to improve nutrient use efficiency is the lack of effective formulations. A phosphite based product, Nutri-phite ( $3 \% \mathrm{~N}, 8.7 \% \mathrm{P}$, and $5.8 \% \mathrm{~K})$ was used as model phosphite formulation for foliar application in winter wheat (Triticum aestivum L). Five field trials were established in the fall of 2009 and 2010 at Perkins, Perry, and Morrison, OK. Treatments encompassed the application of nitrogen (N) at 100 or $75 \%$ of crop need and phosphorus at 100 (P 100\%) and 80\% (P 80\%) sufficiency with and without Nutri-phite. Nutri-phite was applied at one and/or two stages of wheat; GS 13 to 14 and GS 49 to 53 at the rate of 433 and $148 \mathrm{~g} \mathrm{ha}^{-1} \mathrm{P}$ and N, respectively. Grain yield was increased by Nutri-phite treatments, especially at Morrison. Grain P concentration of plots treated with two applications of Nutri-phite ranged from 13 to 55\% more than the nontreated and standard NP received plots at Perkins in 2009/10 and Perry in 2010/11. Grain P uptake was increased due to application of Nutri-phite at Perkins in 2009/10 and Morrison and Perry in 2010/11. Combined over three yearlocations, Nutri-phite increased grain P concentration by 11.6\%. The higher grain P concentration of plots treated with Nutri-phite compared to the other treatments clearly demonstrates its potential in improving P status of wheat grain.
\end{abstract}

\section{Introduction}

Phosphorus is second only to nitrogen in importance as an essential crop nutrient. It is critical for plant growth, especially in the early jointing stages (GS 31 on Zadoks growth stage scale) and for enhancing grain yield and yield components [1]. Phosphorus is important in building energy for metabolism of plant growth through cellular productions such as ATP and ADP from the early stages to the end of the plant's life. It is stored as polyphosphate and in plant vacuole tissue [2]. Several researchers have reported that there are many issues that affect $\mathrm{P}$ availability to the plant when it is applied directly in soil [3-7]. In acidic soil, P is adsorbed by $\mathrm{Al}^{3+}, \mathrm{Fe}^{3+}$, and $\mathrm{Mg}^{2+}$ at soil $\mathrm{pH} 6$ to 6.5 . In alkaline soils, $\mathrm{P}$ is adsorbed by calcium carbonate and becomes unavailable to plants [8]. Moreover, the recycling of
$\mathrm{P}$ in soil is considered slow because it gets fixed and adsorbed on soil particles $[7,8]$. More than $80 \%$ of soil $\mathrm{P}$ is unavailable for plant use $[5,6,8]$. Mosali et al. [5] found that application of broadcast-incorporated preplant fertilizer at 11 to $22 \mathrm{~kg} \mathrm{ha}^{-1}$ $\mathrm{P}$ was required for cereal $[3,4]$. The cost associated with traditionally applied $\mathrm{P}$ fertilizers has also become an issue for many producers, especially as P use efficiency (PUE) is considered very poor because of $\mathrm{P}$ behavior in soil [9].

Foliar fertilization of nutrients, especially $\mathrm{P}$, in major cereal crops has been evaluated to improve nutrient use efficiency $[5,10]$. The time and method of foliar P fertilizer application are critical factors for increasing wheat grain yield. McBeath et al. [11] reported that foliar P fertilizer increased grain yield, grain $\mathrm{P}$ uptake, and the transfer of $\mathrm{P}$ to grain. Sherchand and Paulsen [12] examined four sources of foliar P fertilizer applied at the flowering stage of winter 
wheat and found that the grain yield was increased by foliar $P$ fertilizer with the exception of phytic acid. Shoot growth, leaf area, and chlorophyll of maize were increased by the foliar application of P fertilizer [13]. Mosali et al. [5] reported a linear relationship between $\mathrm{P}$ grain concentration and foliar treatments of $\mathrm{P}$ at Lahoma and a slight effect on $\mathrm{P}$ uptake, especially at second detectable node (GS 32) stage. Phosphorus absorption and metabolism in the plant was very fast when $\mathrm{P}$ was applied as a foliar fertilizer when compared to traditional P soil fertilizer application [14]. Mosali et al. [5] found that delaying foliar $\mathrm{P}$ application to head completely emerged (GS 58) stage increased PUE by $8 \%$ as compared to the same application at GS 32. In corn, Girma et al. [10] reported a greater foliar PUE at $2 \mathrm{~kg} \mathrm{ha}^{-1} \mathrm{P}$ when applied at growth stage V8 compared to 4 and $8 \mathrm{~kg} \mathrm{ha}^{-1} \mathrm{P}$ applied at the same stage. Foliar P increased wheat PUE by $28 \%$ compared with preplant $\mathrm{P}$ fertilizer applied to the soil [15]. There is a need to improve PUE as well as $\mathrm{P}$ concentration in grain and plant tissues. In addition, using foliar $\mathrm{P}$ application methods is considered the best way to reduce the amount of $\mathrm{P}$ fertilizer required as a soil fertilizer.

Many factors affect the absorption or uptake of foliar fertilizer. The first factor is the cuticle layers on the plant leaves. Foliar applied inorganic nutrients are absorbed through leaves in a two-step process in which they penetrate the cuticle (passive percolation or surface adsorption) and then pass through (active absorption) the cells below the cuticle layers [16-20]. Light, temperature, and relative humidity affect the opening of stomata which will, in turn, affect absorption of nutrients $[16,18]$. The uptake of foliar fertilizer is affected by temperature and relative humidity when a thin layer of moisture is formed on the leaves by transpiration [21]. Past research showed that at high temperatures, cuticle adhesiveness increases, surface tension increases, and nutrients are increasingly diffused through the cuticle and stomata [22]. Furthermore, P absorption is also affected by leaf age (upper and lower leaf), wetting of leaf surface, and solution droplet angle [23-25] and solution $\mathrm{pH}[26$, 27]. Phosphorus was rapidly absorbed at low solution $\mathrm{PH}$ compared to high solution PH. Römer and Schilling [1] reported that applied P at GS 31 to 39 (flag leaf ligule and collar visible) at $1 \mathrm{ppm}$ rate increased grain yield compared with GS 75 (medium milk stage) at the same application rate. Several papers reported the impact of foliar P fertilizer on the grain yield of wheat, $\mathrm{PUE}$, and $\mathrm{P}$ grain concentration. Potassium phosphate monobasic $\left(\mathrm{KH}_{2} \mathrm{PO}_{4}\right)$ applied on the wheat canopy at rates of 1 to $4 \mathrm{~kg} \mathrm{ha}^{-1} \mathrm{P}$ increased grain yield in low temperature conditions in China [12]. Another study showed that $\mathrm{KH}_{2} \mathrm{PO}_{4}$ applied at late wheat flowering at rates $0,2.2,4.4$, and $6.6 \mathrm{~kg} \mathrm{ha}^{-1} \mathrm{P}$ and increased grain yield especially at the maximum rate [28].

Research showed that one of the potential hindrances for the use of foliar application as a tool to improve nutrient use efficiency is the lack of a good formulation that can be easily absorbed by cereal leaves [9]. Several products including powdered forms of diammonium phosphate (DAP), triple superphosphate (TSP), monoammonium phosphate (MAP), and potassium phosphate monobasic salt have been evaluated with limited success [15]. Some of these products were not small enough for entry through the leaf, while others, like potassium phosphate monobasic, dried quickly resulting in poor entry into the leaf [10]. Phosphite $\left(\mathrm{PO}_{3}\right)$ based formulations such as Nutri-phite are proposed as alternatives to overcome problems associated with absorption of $\mathrm{P}$ through leaf tissue and to thereby improve nutrient use efficiency, boost crop yield, and increase grain quality $[29,30]$. Nutriphite contains phosphite $\left(\mathrm{PO}_{3}\right)$ and a blend of organic acids that stabilize and safens the phosphite molecule that is taken up by leaves of plants. It is composed of $3 \% \mathrm{~N}$, $8.7 \% \mathrm{P}$, and $5.8 \% \mathrm{~K}$. The compound is designed to improve nutrient use efficiency by plants including major nutrients such as $\mathrm{N}$ and $\mathrm{P}$. Phosphite based formulations have been used in many horticultural crops; however, they have not been tested in major cereals like corn (Zea mays L.) and wheat. In this study, Nutri-phite was used as model phosphite formulation for foliar application in wheat. The goal of most agricultural producers is to obtain optimal crop yields with minimum input from fertilizers and to minimize negative environmental impacts of agricultural operations [30]. It is imperative to evaluate methods to reduce the cost and loss of $\mathrm{P}$ fertilizer critical for wheat producers so that they can achieve their goal.

The hypothesis of this study was the application of phosphite as Nutri-phite with and without the addition of soil applied $\mathrm{P}$ at 100 , and $80 \%$ sufficiency would increase and/or improve growth, grain yield, and grain quality of hard red winter wheat. Thus, the objective of this study was to determine whether phosphite (Nutri-phite) application with or without preplant $\mathrm{P}$ (100 and $80 \%$ sufficiency) fertilizer at two growth stages (GS 13 to 14 and GS 49 to 53 growth stages) at the rate of $4 \mathrm{Lha}^{-1}$ would increase hard red winter wheat grain yield and $\mathrm{P}$ uptake and concentration.

\section{Materials and Methods}

Five winter wheat field experiments were established over the fall of 2009/2010 and 2010/2011 in three locations. Two fields were chosen in 2009/2010, one at Perkins $\left(35^{\circ} 59^{\prime}\right.$ $18.2394^{\prime \prime}$ lat and $-97^{\circ} 2^{\prime} 8.16^{\prime \prime}$ and another at Perry $\left(36^{\circ} 18^{\prime}\right.$ $26.64^{\prime \prime}$ lat and $-97^{\circ} 5^{\prime} 34.0794^{\prime \prime}$ long) (Kirkland fine, mixed, superactive, thermic Udertic Paleustolls). In 2010/2011 the study was conducted at Perkins, Perry, and Morrison $\left(36^{\circ}\right.$ $16^{\prime} 42.2394^{\prime \prime}$ lat and $\left.-97^{\circ} 3^{\prime} 51.48^{\prime \prime}\right)$. The soil at Perkins is Kirkland silt loam-fine, mixed, thermic Udertic Paleustoll and that of Perry is Norge fine-silty, mixed, active, thermic Udic Paleustolls Morrison, while that of Morrison is Grainola fine, mixed, active, thermic Udertic Haplustalfs. A total of 8 treatments were arranged in a randomized complete block design with three replications. Plot size was $6 \mathrm{~m}$ by $3 \mathrm{~m}$ with a $3 \mathrm{~m}$ alley between replicates.

2.1. Treatments and Treatments Structure. Treatments encompassed one or two application of Nutri-phite at 2-4 leaf stage (GS 12 to 14, henceforth referred as Nutrlx) or 2-4 leaf and booting/flowering (GS 49 to 53, henceforth referred to as Nutr2x) with or without preplant $\mathrm{N}$ and $\mathrm{P}$ fertilizers. Table 1 
presents the description and abbreviations of treatments considered in this study.

2.2. Soil Samples and Fertilizer Application. Soil samples were collected and analyzed from 0 to $30 \mathrm{~cm}$ ( $1 \mathrm{ft}$ ) for available $\mathrm{N}$ and $\mathrm{P}$ in the soil prior to initiation of the experiment. This information was used to calculate $\mathrm{N}$ and $\mathrm{P}$ fertilizer needed to achieve yield goal of $3 \mathrm{tha}^{-1}$ in the case of $\mathrm{N}$ and $100 \%$ and $80 \%$ sufficiency in the case of P [31]. The full (100\%) N rate was set to $112 \mathrm{~kg} \mathrm{ha}^{-1} \mathrm{~N}$ to achieve the yield goal. Nitrogen as urea $(46 \% \mathrm{~N}-0 \% \mathrm{P}-0 \% \mathrm{~K})$ was split $1 / 3$ and $2 / 3$ between preplant and jointing stage, respectively. All soil applied $\mathrm{P}$ was determined based on percentage sufficiency and was applied as a preplant application using triple superphosphate $(0 \% \mathrm{~N}$ $20 \% \mathrm{P}-0 \% \mathrm{~K})$. Phosphorus was applied at 17.5 and $20.8 \mathrm{~kg} \mathrm{ha}^{-1}$ $\mathrm{P}$ to attain 80 and $100 \%$ sufficiency. Based on soil analysis results, $\mathrm{K}$ was not needed for any of the experimental sites (Table 2). Nutri-phite was applied using SRS-540 Propack rechargeable electric backpack sprayers (Shurflo, Cypress, CA) that covers approximately $2 \mathrm{~m}$ width over the wheat canopy at the rate of 433 and $148 \mathrm{~g} \mathrm{ha}^{-1} \mathrm{P}$ and $\mathrm{N}$, respectively, based on solution density of $1.24 \mathrm{~kg} \mathrm{~L}^{-1}$ at each growth stage. About $100 \mathrm{~mL}$ of Nutri-phite was added to $1 \mathrm{~L}$ of water to make a spray solution.

2.3. Experimental Management. Duster winter wheat was notill planted on November 6, 2009 at Perry and November 18, 2009 at Perkins. Endurance winter wheat was no-till planted October 8, 2010 at Perry and Morrison and on October 11, 2010 at Perkins. Duster was replaced with Endurance to avoid a potential confounding effect and yield loss that would have been incurred due to a new strip rust race. The two varieties share similar growth habit and maturity dates. In both years varieties were planted in $19.5 \mathrm{~cm}$ row spacing at the rate of $101 \mathrm{~kg} \mathrm{ha}^{-1}$ at all sites. The first application of Nutri-phite was carried out in mid-March in each year at Perkins and late-March in Perry and Morrison areas in both years. The second Nutri-phite application was performed in late April to early May in each year. All dates corresponded to the actual growth stages specified in Table 1 . In both years, weeds were controlled with a tank mix of $1.2 \mathrm{~L} \mathrm{ha}^{-1} 2,4-\mathrm{D}$ amine and $91 \mathrm{~g} \mathrm{ha}^{-1}$ sulfosulfuron applied at 3 to 4 leaf stage GS 32 .

2.4. Data Collection and Analysis. Primary data included productive tillers per plant at harvesting stage, plant height $(\mathrm{cm})$ at physiological maturity, grain yield $\left(\mathrm{kg} \mathrm{ha}^{-1}\right)$, grain $\mathrm{P}$ concentration $\left(\mathrm{mg} \mathrm{kg}^{-1}\right)$, and gain $\mathrm{P}$ uptake. Wheat was harvested at maturity by harvesting the center $2 \mathrm{~m}$ using a Massey Ferguson 8XP experimental combine. The combine was equipped with a Harvest Master automated weighing system (Harvest Master Inc., Logan, Utah). Grain subsamples from each treatment were collected for determining grain $\mathrm{P}$ concentration. The subsamples were dried in a forced air oven at $66^{\circ} \mathrm{C}$, ground to pass a 140 mesh sieve $(100 \mathrm{~mm})$, and analyzed for total $\mathrm{P}$ using inductively coupled plasma mass spectrometry (PerkinElmer, Waltham, MA) after a wet acid digestion [32]. Grain yield was adjusted to a $12.5 \%$ moisture level. Phosphorus uptake was calculated by multiplying grain $\mathrm{P}$ concentration by grain yield. Data were subjected to ANOVA using GLM/MIXED procedures of SAS 9.3 in SAS (SAS institute, Cary, NC). Before testing hypotheses and assumptions of normality and homogeneity of variance were checked for all measured variables using the UNIVARIATE procedure and Levene's homogeneity of variance test, respectively. Very few outliers were identified and removed from the data. Treatment comparisons were made using protected Duncan's multiple range at $P \leq 0.05$ and single-degree-of-freedom contrast analysis.

\section{Results and Discussion}

The analysis of variance (ANOVA) showed that locations and treatments significantly affected grain yield, grain $\mathrm{P}$ concentration, and P uptake over the two years of the study (Table 3). Productive tillers per plant at harvesting stage were recorded in 2009/10 only. Plant height $(\mathrm{cm})$ at physiological maturity was not affected by treatments and thus results are not included for this measurement.

Further, the ANOVA showed that no measured or calculated variables were influenced by treatment at Perkins in 2010/11. Results were influenced by soil conditions of each field (Table 2) and to precipitation distribution (Figure 1).

Oklahoma Mesonet temperature record did not show a trend out of the ordinary for all site-years (data not shown). The total precipitation during the winter wheat growing seasons was above the amount recommended for wheat in Oklahoma $(575 \mathrm{~mm})$ at Perkins and Stillwater in 2009/10. A lower than optimum precipitation at Perkins and Stillwater were recorded in the second growing season (507 and $440 \mathrm{~mm}$, resp.). The distribution of precipitation during peak winter wheat growth stage (booting and grain filling) overlapped with low precipitation in March and April, relative to later months consistently across year-site.

3.1. Grain Yield. Grain yield was significantly affected by treatments among the locations (Table 4). In 2009/2010, at Perkins and Perry study sites, there was no significant effect of treatments on grain yield. In 2010/11 at Perkins, all treatments had significantly higher yield than the nontreated plots (Table 4). However, yield was not different among Nutriphite, soil applied $\mathrm{N}$ and $\mathrm{P}$ fertilizers, or their combination. In 2010/11, at Morrison grain yield increased due to application of Nutri-phite compared to control treatments. Nutri-phite resulted in $70 \%$ more grain yield than the nontreated. At this location in 2010/11 Nut2x in combination with N 75\% and P $80 \%$ increased grain yield by $520 \mathrm{~kg} \mathrm{ha}^{-1}$ compared to $\mathrm{N}$ $75 \%$ and $\mathrm{P} 80 \%$ treatment (without Nutri-phite). At Perry in 2010/11, Nutri-phite did not significantly increase grain yield compared to standard treatment (NP 100\%). Likewise, there was no grain yield difference between Nutri-phite, nontreated, and P 100\% treatments. Additionally, at Perry in 2010/11, grain yield increased $\left(254 \mathrm{~kg} \mathrm{ha}^{-1}\right)$ by using Nutriphite in combination with $\mathrm{N} 75 \%$ and $\mathrm{P} 80 \%$ compared to $\mathrm{N}$ $75 \%$ and P $80 \%$ without Nutri-phite, regardless of application frequency. However, there was no significant grain yield 
TABLE 1: Treatment structure and abbreviations of Nutri-phite and soil applied fertilizers in hard red winter wheat in 2009/2010 and 2010/2011 cropping seasons in Oklahoma.

\begin{tabular}{lc}
\hline Treatment Structure & Abbreviations \\
\hline No fertilizer control & Nontreated \\
Nutri-phite at $2-4$ leaf stage ${ }^{\dagger}$ and booting/flowering & Nutr2x \\
N at 100\% crop need ${ }^{\ddagger}$ and P at 100\% Sufficiency & NP 100\% \\
P applied at 100\% sufficiency & $P$ 100\% \\
P applied at 100\% sufficiency + Nutri-phite at 2-4 leaf stage & P 100\% + Nutrlx \\
P applied at 100\% sufficiency + Nutri-phite at 2-4 leaf stage \& booting/flowering & P 100\% \& Nutr2x \\
N applied at 75\% of crop need and P applied at 80\% sufficiency & N 75\% \& P 80\% \\
N applied at 75\% of crop need and P applied at 80\% sufficiency + Nutri-phite at 2-4 leaf stage \& & N 75\% \& P 80\% \& Nutr2x \\
booting/flowering & ${ }^{\dagger}$ Treatments applied within a production year. Nutrlx: one application of Nutri-phite at 2-4 leaf stage (GS 12 to 14). Nutr2x: two applications of Nutri-phite at \\
GS 2-4 and booting to flowering stages (GS 49-53). &
\end{tabular}

TABLE 2: Initial 0 to $30 \mathrm{~cm}$ (1 ft) soil test $\mathrm{NO}_{3}-\mathrm{N}$, P, and $\mathrm{K}$ in hard red winter wheat grown field at five site locations in 2009/2010 and 2010/2011 winter wheat cropping seasons in $\mathrm{OK}$.

\begin{tabular}{|c|c|c|c|c|c|c|}
\hline \multirow{3}{*}{ Location } & \multicolumn{3}{|c|}{$2009 / 2010$} & \multicolumn{3}{|c|}{ 2010/2011 } \\
\hline & $\mathrm{NO}_{3}-\mathrm{N}+\mathrm{NH}_{4}-\mathrm{N}^{\dagger}$ & $\mathrm{P}$ & $\mathrm{K}$ & $\mathrm{NO}_{3}-\mathrm{N}+\mathrm{NH}_{4}-\mathrm{N}$ & $\mathrm{P}$ & K \\
\hline & \multicolumn{3}{|c|}{$\mathrm{kg} \mathrm{ha}^{-1}$} & \multicolumn{3}{|c|}{$\mathrm{kg} \mathrm{ha}^{-1}$} \\
\hline Perkins & 28 & 45 & 300 & 27 & 43 & 297 \\
\hline Perry & 34 & 39 & 295 & 25 & 42 & 302 \\
\hline Morrison & -9 & - & - & 45 & 17 & 284 \\
\hline
\end{tabular}

${ }^{\dagger} \mathrm{NO}_{3}-\mathrm{N} \mathrm{NH}_{4}$-N was extracted with $2 \mathrm{M} \mathrm{KCl}$ solution, and $\mathrm{P}$ and $\mathrm{K}$ were extracted with Mehlich III solution. ${ }^{9}$ data were not available.

difference between Nutri-phite and preplant P 100\% in both fields (Morrison and Perry) in 2010/11. The current results agreed with Mosali et al. [5] and Torres [15] who found a negligible effect of foliar $\mathrm{P}$ on the grain yield of wheat especially at G32 (second detectable node) as foliar P was applied with a preplant fertilizer. In contrast, the application of $2 \mathrm{~kg} \mathrm{ha}^{-1} \mathrm{P}$ foliar at the V8 (collar of eighth leaf unfolded) corn growth stage affected yield and PUE [9]. This could be attributed to variations in soil and weather conditions, especially moisture (Figure 1). Moisture and temperature may affect the opening of the stomata, which consequently may affect absorption and the movement of Nutri-phite throughout leaf tissues. Light, temperature, and relative humidity are the most critical environmental conditions influencing the opening of the stomata, which then affect absorption and evaporation of foliar nutrient $[16,18,21,22]$. The lack of response to $\mathrm{P}$ at Perkins and Perry in 2009/2010 could also be due to the high levels of $\mathrm{P}$ concentration in the soils of this study (Table 2) making the effect of additional $\mathrm{P}$ fertilizer minimal.

3.2. Grain Phosphorus Concentration. Although there was no significant effect of treatment on grain yield at Perkins in 2009/10, grain P concentration was significantly affected by treatments (Table 5). Nutri-phite treatment resulted in greater grain $\mathrm{P}$ concentration $\left(4095 \mathrm{mg} \mathrm{kg}^{-1}\right.$ ) compared to nontreated and NP 100\% (745 and $815 \mathrm{mg} \mathrm{kg}^{-1}$ more, resp.). In 2010/11 at Perry, application of Nutri-phite at the two growth

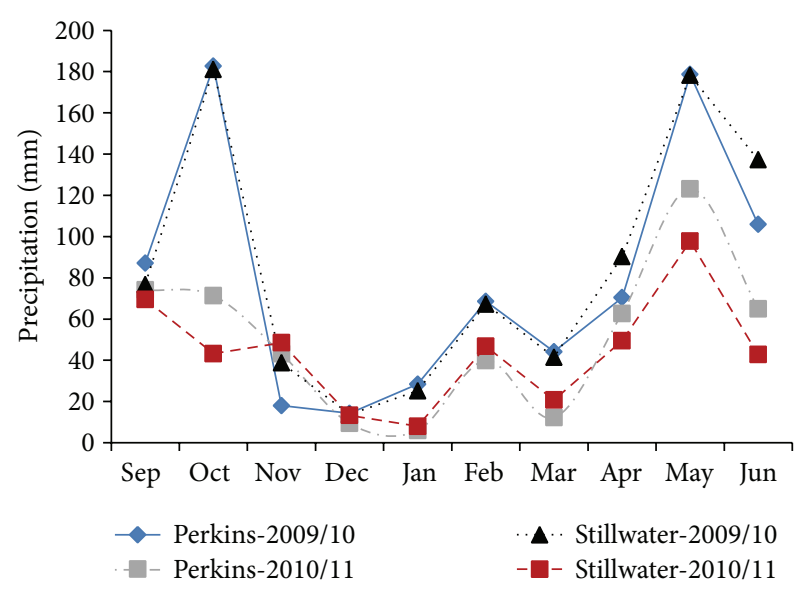

FIGURE 1: Precipitation at closest weather stations to Morrison and Perry (Stillwater Mesonet station) and Perkins in 2009/10 and 2010/11 winter wheat growing seasons.

stages of wheat (Nutr2x) with preplant $\mathrm{P} 100 \%$ resulted in highest grain $\mathrm{P}$ concentration (3950 $\mathrm{mg} \mathrm{kg}^{-1}$ ). Similarly, application of Nutr2x with preplant $\mathrm{N}$ and/or $\mathrm{P}$ at both sufficiency levels resulted in higher grain $\mathrm{P}$ concentration than the NP 100\% treatment. However, the effect of Nutriphite was not consistent among the treatments at both locations. Grain P concentration of wheat might be increased, when foliar $\mathrm{P}$ was sprayed at anthesis [12]. The higher grain $\mathrm{P}$ 
TABLE 3: Analysis of variance for grain yield $\left(\mathrm{kg} \mathrm{ha}^{-1}\right)$, grain $\mathrm{P}$ concentration $\left(\mathrm{mg} \mathrm{kg}^{-1}\right)$, and $\mathrm{P}$ uptake $\left(\mathrm{kg} \mathrm{ha}^{-1}\right)$ in winter wheat as affected by treatments in five fields at three locations (Perkins, Perry, and Morrison, OK), over 2009/10 and 2010/11.

\begin{tabular}{lcccc}
\hline Source of variation & Grain yield $\left(\mathrm{kg} \mathrm{ha}^{-1}\right)$ & Grain P concentration $\left(\mathrm{mg} \mathrm{kg}^{-1}\right)$ & $\mathrm{P}$ uptake $\left(\mathrm{kg} \mathrm{ha}^{-1}\right)$ & Productive tillers (no/main shoot) \\
\hline Location & $* * *^{\$}$ & $* *$ & $* *$ & $*$ \\
Year & $\mathrm{NS}$ & $*$ & $\mathrm{NS}$ & - \\
Treatments & $*$ & $*$ & $\mathrm{~N}$ & $*$ \\
Location $*$ treatments & $\mathrm{NS}$ & $\mathrm{NS}$ & $\mathrm{NS}$ \\
Year $*$ treatments & $\mathrm{NS}$ & $\mathrm{NS}$ & $\mathrm{NS}$ & $\mathrm{NS}$ \\
\hline$R$-Square & 0.53 & 0.74 & 0.73 & 0.76 \\
\hline
\end{tabular}

$\$ *, * * \& * * *$ : Significant at $P \leq 0.05,0.01$, and 0.001 , respectively; ${ }^{\circledR}$ NS: nonsignificant. ${ }^{9}$ Data were available only in $2009 / 2010$ cropping seasons.

TABle 4: Mean winter wheat grain yield $\left(\mathrm{kg} \mathrm{ha}^{-1}\right)$ as affected by treatments at Perkins and Perry in 2009/2010 and at Perkins, Morrison, and Perry in 2010/2011.

\begin{tabular}{|c|c|c|c|c|c|}
\hline \multirow[b]{2}{*}{ Treatment } & \multicolumn{2}{|c|}{$2009 / 2010$} & \multirow[b]{2}{*}{$\begin{array}{l}\text { Perkins } \\
\text { Grain yield }\left(\mathrm{kg} \mathrm{ha}^{-1}\right)\end{array}$} & \multirow[b]{2}{*}{ Morrison } & \multirow{2}{*}{$\begin{array}{c}\text { 2010/2011 } \\
\text { Perry }\end{array}$} \\
\hline & Perkins & Perry & & & \\
\hline Nontreated & 1049 & 1429 & $698 \mathrm{~b}$ & $873 c^{\ddagger}$ & $471 \mathrm{c}$ \\
\hline NP 100\% & 1314 & 1622 & $1413 \mathrm{a}$ & $1355 \mathrm{abc}$ & $1138 \mathrm{a}$ \\
\hline Nutr $2 x^{\dagger}$ & 1270 & 1277 & $1305 \mathrm{a}$ & $1498 \mathrm{ab}$ & $434 \mathrm{c}$ \\
\hline P $100 \%$ only & 1178 & 1602 & $1191 \mathrm{a}$ & $1744 \mathrm{a}$ & $560 \mathrm{cb}$ \\
\hline P 100\% + Nutrlx & 1420 & 1113 & $1527 \mathrm{a}$ & $1497 \mathrm{ab}$ & $481 \mathrm{c}$ \\
\hline P $100 \%+$ Nutr $2 x$ & 1290 & 1123 & $1321 \mathrm{a}$ & $1025 \mathrm{bc}$ & $525 \mathrm{c}$ \\
\hline N 75\% \& P 80\% only & 1231 & 1274 & $1236 \mathrm{a}$ & $1289 \mathrm{abc}$ & $969 \mathrm{ab}$ \\
\hline N 75\% \& P 80\% + Nutr2x & 867 & 1406 & -9 & 1809 a & $1223 \mathrm{a}$ \\
\hline Duncan's multiple range & $\mathrm{NS}^{\S}$ & NS & 490 & 506 & 439 \\
\hline
\end{tabular}

${ }^{\dagger}$ Nutrlx: one application of Nutri-phite at 2-4 leaf stage (GS 12 to 14); Nutr2x: two applications of Nutri-phite at GS 2-4 and booting to flowering stages (GS 4953); ${ }^{\ddagger}$ down a column, means followed by the same letter are not significantly different at $P \leq 0.05$ based on Duncan’s multiple range test); ${ }^{\circledR}$ NS: nonsignificant; data were not available.

concentration of plots treated with foliar Nutri-phite clearly demonstrates its potential in improving $\mathrm{P}$ status of wheat grain. Phosphorus is an essential nutrient for a healthy life due to its role in bone and teeth formation and maintenance, improved digestion, energy storage, and protein and hormone synthesis [33-35]. Harder et al. [36] reported that P in grain was increased by $4.7 \%$ by foliar fertilization compared with the control. Furthermore, Pellerin et al. [37] concluded that high $\mathrm{P}$ concentration in grain might improve yield or be kept in the seed as $\mathrm{P}$, which is ultimately needed for germination and initial development of seedlings. The low grain $\mathrm{P}$ concentration in the $\mathrm{N}$ received treatments might be attributed to the inverse concentration relationship of the two nutrients. Coblentz et al. [38] reported a decline in $\mathrm{P}$ concentration in the forage of bermudagrass with increase in nitrogen rate.

3.3. Phosphors Uptake. The results of $\mathrm{P}$ uptake $\left(\mathrm{kg} \mathrm{ha}^{-1}\right)$ showed that there was no significant effect of treatment at Perry site in both 2009 and 2010 (Table 6). The effect of treatments on grain P uptake was not consistent across siteyears. At Perkins, the highest $\mathrm{P}$ uptake (166\% more than $\mathrm{N}$ $75 \%$ and P $80 \%$ treatment) was exhibited with the Nutr2x treatment (Table 6) followed by NP $100 \%$ with or without Nutrlx. The grain P uptake of the nontreated treatment was not significantly different from the Nutr2x or any other treatment at this location. A contrast between Nutri-phite applied versus preplant fertilizer applied plots did not result in a statistically significant $\mathrm{P}$ uptake (data not shown). At Morrison in 20010/11, grain P uptake was greatest with the $\mathrm{N}$ $75 \%$ and $\mathrm{P} 80 \%+$ Nutr2x treatment. This treatment resulted in $136 \%$ more grain $\mathrm{P}$ uptake than the nontreated plots. Applying Nutri-phite in this field with or without preplant fertilizer did increase P uptake by more than $80 \%$ compared to the nontreated.

Similar to Perkins in 2009/2010, at Perry in 2010/11 the application of Nutri-phite with and without preplant fertilizer did not significantly increase P uptake. Over all, using Nutriphite with and without preplant fertilizer did not increase $\mathrm{P}$ uptake compared to only preplant fertilizer application (both $\mathrm{N}$ and $\mathrm{P}$ ). However, averaged over locations that showed significant treatment effect, Nutri-phite application improved grain $\mathrm{P}$ uptake compared with the nontreated check. In all locations in 2010/11 rainfall during the peak crop growth was suboptimal (Figure 1) which might have interfered with $\mathrm{P}$ assimilation into grain. It could also be due to high soil $\mathrm{P}$ amount and other growing conditions $[16,18,21,22]$. The 
TABle 5: Mean winter wheat grain $P$ concentration $\left(\mathrm{mg} \mathrm{kg}^{-1}\right)$ as affected by treatments at Perkins and Perry in 2009/2010 and at Perkins, Morrison, and Perry in 2010/2011.

\begin{tabular}{|c|c|c|c|c|c|}
\hline \multirow{3}{*}{ Treatment } & \multicolumn{2}{|c|}{$2009 / 2010$} & \multirow{3}{*}{$\begin{array}{l}\text { Perkins } \\
\text { Grain yield }\left(\mathrm{kg} \mathrm{ha}^{-1}\right)\end{array}$} & \multirow{3}{*}{ Morrison } & \multirow{3}{*}{$\begin{array}{c}\text { 2010/2011 } \\
\text { Perry }\end{array}$} \\
\hline & Perkins & Perry & & & \\
\hline & & & & & \\
\hline Nontreated & $3350 \mathrm{~b}^{\ddagger}$ & 4450 & $3365 \mathrm{a}$ & 2605 & $3485 \mathrm{abc}$ \\
\hline NP 100\% & $3280 \mathrm{~b}$ & 3675 & $3405 \mathrm{a}$ & 2770 & $2545 \mathrm{~d}$ \\
\hline Nutr $2 x^{\dagger}$ & $4095 \mathrm{a}$ & 4355 & $3625 \mathrm{a}$ & 2915 & $2830 \mathrm{bcd}$ \\
\hline P $100 \%$ only & $3372 \mathrm{ab}$ & 3055 & $3090 \mathrm{a}$ & 2585 & $3470 \mathrm{abc}$ \\
\hline P $100 \%$ + Nutrlx & $3627 \mathrm{ab}$ & 3825 & $3520 \mathrm{a}$ & 2405 & $3650 \mathrm{ab}$ \\
\hline$P 100 \%+$ Nutr $2 x$ & $3232 \mathrm{~b}$ & 4245 & $2940 \mathrm{a}$ & 2735 & $3950 \mathrm{a}$ \\
\hline N 75\% \& P 80\% only & $3475 \mathrm{ab}$ & -9 & $3475 \mathrm{a}$ & 2785 & $3180 \mathrm{abcd}$ \\
\hline N 75\% \& P 80\% + Nutr2x & $3710 \mathrm{ab}$ & - & - & 2935 & $2765 \mathrm{~cd}$ \\
\hline Duncan's multiple range & 731 & $\mathrm{NS}^{\S}$ & 689 & NS & 830 \\
\hline
\end{tabular}

${ }^{\dagger}$ Nutrlx: one application of Nutri-phite at 2-4 leaf stage (GS 12 to 14); Nutr2x: two applications of Nutri-phite at GS 2-4 and booting to flowering stages (GS 49$53) ;{ }^{\ddagger}$ down a column, means followed by the same letter are not significantly different at $P \leq 0.05$ based on Duncan's multiple range test); ${ }^{\circledR}$ NS: nonsignificant; data were not available.

TAble 6: Mean winter wheat P uptake $\left(\mathrm{kg} \mathrm{ha}^{-1}\right)$ as affected by treatments at Perkins and Perry in 2009/2010 and at Perkins, Morrison and Perry in 2010/2011.

\begin{tabular}{|c|c|c|c|c|c|}
\hline Treatment & Perkins & Perry & $\begin{array}{c}\text { Perkins } \\
\text { P uptake }\left(\mathrm{kg} \mathrm{ha}^{-1}\right)\end{array}$ & Morrison & Perry \\
\hline Nontreated & $3.36 \mathrm{ab}$ & 4.39 & 2.24 & $2.08 \mathrm{~b}^{\ddagger}$ & 2.00 \\
\hline NP 100\% & $4.66 \mathrm{a}$ & 6.02 & 5.31 & $3.69 \mathrm{ab}$ & 3.17 \\
\hline Nutr2x $x^{\dagger}$ & $4.98 \mathrm{a}$ & 4.74 & 4.21 & $3.89 \mathrm{ab}$ & 1.91 \\
\hline P $100 \%$ only & $4.03 \mathrm{ab}$ & 4.12 & 4.14 & $4.52 \mathrm{ab}$ & 2.32 \\
\hline P $100 \%+$ Nutrlx & $4.40 \mathrm{a}$ & 4.19 & 4.04 & $3.10 \mathrm{ab}$ & 1.79 \\
\hline P $100 \%+$ Nutr $2 x$ & $3.29 \mathrm{ab}$ & 5.28 & 2.03 & $2.92 \mathrm{ab}$ & 2.12 \\
\hline N 75\% \& P 80\% & $1.87 \mathrm{~b}$ & -9 & 2.00 & $3.61 \mathrm{ab}$ & 2.48 \\
\hline N 75\% \& P 80\% + Nutr2x & $2.76 \mathrm{ab}$ & - & 3.5 & $4.91 \mathrm{a}$ & 2.12 \\
\hline Duncan's multiple range & 2.20 & $\mathrm{NS}^{\S}$ & NS & 2.51 & NS \\
\hline
\end{tabular}

${ }^{\dagger}$ Nutrlx: one application of Nutri-phite at 2-4 leaf stage (GS 12 to 14); Nutr2x: two applications of Nutri-phite at GS 2-4 and booting to flowering stages (GS 4953); ${ }^{\ddagger}$ down a column, means followed by the same letter are not significantly different at $P \leq 0.05$ based on Duncan’s multiple range test); ${ }^{\circledR}$ NS: nonsignificant; 'data were not available.

results of this study agreed with $[5,15]$, where $\mathrm{P}$ uptake was increased with foliar P fertilizer.

3.4. Productive Tillers. Tillers per plant were significant at Perkins $(P<0.01)$ and at Perry $(P<0.001)$ in $2009 / 2010$. At Perkins, NP $100 \%$ treatment had the highest number of tillers followed by N 75\% and P 80\% + Nutr2x treatment, which was not different from the other treatments except the check and P $100 \%$ only treatments. The Nutr $2 x$ treatment did not result in more tillers than any treatment.

At Perry in 2009/10, Nutr2x, NP 100\%, and N 75\% and P $80 \%+$ Nutr $2 x$ had the greatest number of tillers. The Nutr $2 x$ treatment had 1.2 and 0.5 more tillers than the P $100 \%, \mathrm{~N}$ $75 \%$, and P $80 \%$ treatments, respectively (Figure 2). Results suggested the importance of both soil applied nutrients as well as foliar supplement for increasing number of tillers per plant. The number of tillers at Perkins and Perry was significantly correlated with grain yield $(r=0.6, P<0.0001$ and $r=0.6, P<0.01$, resp.). Increase in tiller number is associated with increased yield [39]. Rodríguez et al. [40] reported that there was a significant effect of foliar P fertilizer on corn shoot growth. In addition, fertile tillers of winter wheat were increased by using foliar P fertilizer at early stages $[6,11,41]$.

\section{Conclusions}

Nutri-phite (Nutr1x and Nutr2x) with and without preplant fertilizer in all fields did not affect grain yield of wheat, but there was a significant effect on grain P concentration. Grain yield determined by ANOVA was marginally increased by the combination of Nutri-phite (Nutrlx and Nutr2x) with $\mathrm{N} 75 \%$ and $\mathrm{P} 80 \%$, but the $100 \%$ preplant $\mathrm{P}$ treatment was not consistent in grain yield. There was significant difference between Nutri-phite (Nutr2x) and check treatment (nontreated) in grain yield. Nutri-phite (Nutr2x) resulted in more grain $\mathrm{P}$ concentration compared to nontreated and NP $100 \%$ treatment. Likewise, combining Nutri-phite (Nutrlx and Nutr2x) with P 100\% treatments resulted in increase in 


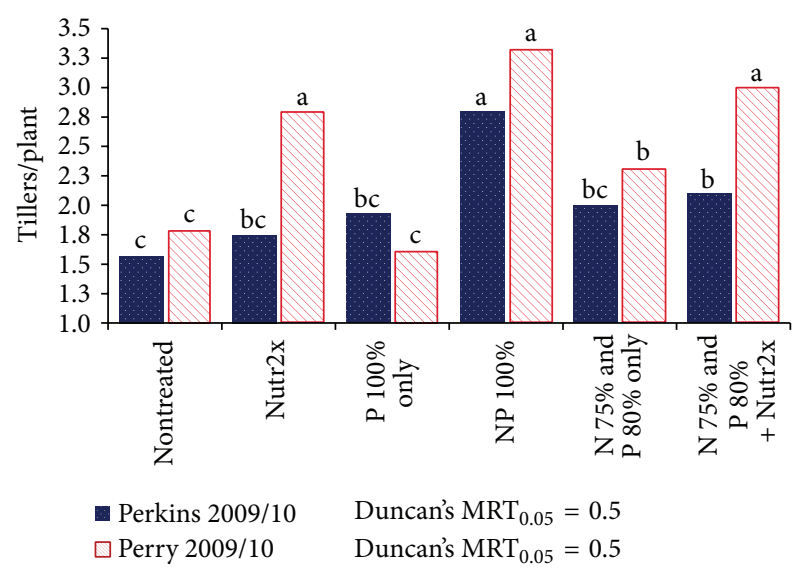

FIgURE 2: Winter wheat productive tiller number as influenced by treatments at Perkins and Perry in 2009/2010. Within each site, bars followed by the same letter are not statistically different using Duncan's multiple range test (Duncan's MRT).

grain $\mathrm{P}$ concentration. Combined over three year-locations, Nutri-phite increased grain P concentration by $11.6 \%$. The $\mathrm{P}$ uptake of grain was increased by Nutri-phite application, especially with Nutr2x compared to nontreated. Nutri-phite treatments resulted in more $\mathrm{P}$ uptake than preplant applied $\mathrm{P}$. This study demonstrated that the application of Nutri-phite treatments as foliar P fertilizer might enhance and/or improve the wheat grain yield and grain quality, especially under good environmental conditions. Additionally, future foliar $\mathrm{P}$ fertilization should focus on the amount of foliar fertilizer applied and the best time of the crop life cycle to get the benefit of foliar application. Our results conform to previous finding that foliar P should be used to supplement soil applied $\mathrm{P}$ to improve wheat quality as demonstrated through high grain $\mathrm{P}$ concentration.

\section{Disclaimer}

The mentioning of a trade name or commercial product in this paper does not constitute endorsement or recommendation of this product by the authors.

\section{Conflict of Interests}

The authors declare that there is no conflict of interests regarding the publication of this paper.

\section{References}

[1] W. Römer and G. Schilling, "Phosphorus requirements of the wheat plant in various stages of its life cycle," Plant and Soil, vol. 91, no. 2, pp. 221-229, 1986.

[2] H. Maschner, Mineral Nutrition of Higher Plants, Academic Press, London, UK, 2nd edition, 1995.

[3] D. H. Sander, E. J. Penas, and D. T. Walters, "Winter wheat phosphorus fertilization as influenced by glacial till and loess soils," Soil Science Society of America Journal, vol. 55, no. 5, pp. 1474-1479, 1991.
[4] D. H. Sander, E. J. Penas, and B. Eghball, "Residual effects of various phosphorus application methods on winter wheat and grain sorghum," Soil Science Society of America Journal, vol. 54, no. 5, pp. 1473-1478, 1990.

[5] J. Mosali, K. Desta, R. K. Teal et al., "Effect of foliar application of phosphorus on winter wheat grain yield, phosphorus uptake, and use efficiency," Journal of Plant Nutrition, vol. 29, no. 12, pp. 2147-2163, 2006

[6] G. D. Batten, "A review of phosphorus efficiency in wheat," Plant and Soil, vol. 146, no. 1-2, pp. 163-168, 1992.

[7] D. P. Schachtman, R. J. Reid, and S. M. Ayling, "Phosphorus uptake by plants: from soil to cell," Plant Physiology, vol. 116, no. 2, pp. 447-453, 1998.

[8] W. L. Lindsay, P. L. G. Vlek, and S. H. Chien, "Phosphate minerals," in Minerals in Soil Environment, J. B. Dixon and S. B. Weed, Eds., pp. 1089-1130, Soil Science Society of America, Madison, Wis, USA, 2nd edition, 1989.

[9] D. Tilman, J. Fargione, B. Wolff et al., "Forecasting agriculturally driven global environmental change," Science, vol. 292, no. 5515, pp. 281-284, 2001.

[10] K. Girma, K. L. Martin, K. W. Freeman et al., "Determination of optimum rate and growth stage for foliar-applied phosphorus in corn," Communications in Soil Science and Plant Analysis, vol. 38, no. 9-10, pp. 1137-1154, 2007.

[11] T. M. McBeath, M. J. McLaughlin, and S. R. Noack, "Wheat grain yield response to and translocation of foliar-applied phosphorus," Crop and Pasture Science, vol. 62, no. 1, pp. 58-65, 2011.

[12] K. Sherchand and G. M. Paulsen, "Response of wheat to foliar phosphorus treatments under field and high temperature regimes," Journal of Plant Nutrition, vol. 8, no. 12, pp. 1171-1181, 1985.

[13] F. Ling and M. Silberbush, "Response of maize to foliar vs. soil application of nitrogen-phosphorus-potassium fertilizers," Journal of Plant Nutrition, vol. 25, no. 11, pp. 2333-2342, 2002.

[14] D. Boyton, "Nutrition by foliar application," Annual Review of Plant Physiology, vol. 5, pp. 31-54, 1954.

[15] G. M. Torres, Foliar phosphorus fertilization and the effect of surfactants on winter wheat Triticum aestivum L [M.S. thesis], Oklahoma State University, 2011.

[16] S. Kannan, "Physiology of foliar uptake of inorganic nutrients," Proceedings: Plant Sciences, vol. 96, no. 6, pp. 457-470, 1986.

[17] M. T. Tyree, T. D. Scherbatskoy, and C. A. Tabor, "Leaf cuticles behave as asymmetric membranes: evidence from the measurement of diffusion potentials," Plant Physiology, vol. 92, no. 1, pp. 103-109, 1990.

[18] S. R. Noack, T. M. McBeath, and M. J. McLaughlin, "Potential for foliar phosphorus fertilisation of dryland cereal crops: a review," Crop and Pasture Science, vol. 61, no. 8, pp. 659-669, 2010.

[19] M. G. Erwee, P. B. Goodwin, and A. J. E. Van Bel, "Cell-cell communication in the leaves of commellina cyanea and other plants," Plant, Cell and Environment, vol. 8, no. 3, pp. 173-178, 1985.

[20] S. Kannan, "Foliar absorption and transport of inorganic nutrients," Critical Reviews in Plant Sciences, vol. 4, no. 4, pp. 347-376, 1986.

[21] G. N. Thorne, "Factors affecting uptake of radioactive phosphorus by leaves and its translocation to other parts of the plant," Annals of Botany, vol. 22, no. 3, pp. 381-398, 1958. 
[22] R. C. Kirkwood, "Recent developments in our understanding of the plant cuticle as a barrier to the foliar uptake of pesticides," Pesticide Science, vol. 55, no. 1, pp. 69-77, 1999.

[23] H. Koontz and O. Biddulph, "Factors affecting absorption and translocation of foliar applied phosphorus," Plant Physiology, vol. 32, no. 5, pp. 463-470, 1957.

[24] S. H. Witter and F. G. Teubner, "Foliar absorption of mineral nutrients," Annual Review of Physiology, vol. 10, pp. 13-30, 1959.

[25] D. W. Reed and H. B. Jr. Tukey, "Factors affecting foliar absorption of nutrients by selected landscape and herbaceous plants," Journal of Environmental Horticulture, vol. 5, no. 2, pp. 72-76, 1987.

[26] E. G. Fisher and D. R. Walker, "The apparent absorption of P and $\mathrm{Mg}$ from sprays applied to the lower surface of 'McIntosh'apple leaves," Proceedings of the American Society for Horticultural Science, vol. 65, pp. 17-24, 1955.

[27] S. Kannan, "Mechanism of foliar uptake of plant nutrients: accomplishments and prospects," Journal of Plant Nutrition, vol. 2, no. 6, pp. 717-735, 1980.

[28] M. Benbella and G. M. Paulsen, "Efficacy of treatments for delaying senescence of wheat leaves: II. Senescence and grain yield under field conditions," Agronomy Journal, vol. 90, no. 3, pp. 332-338, 1998.

[29] W. Biagro, “Nutri-phite," 2006, http://www.biagro.com/Nutriphitei_phite/np_html.

[30] C. Morel and J. C. Fardeau, "Uptake of phosphate from soils and fertilizers as affected by soil $P$ availability and solubility of phosphorus fertilizers," Plant and Soil, vol. 121, no. 2, pp. 217224, 1990.

[31] G. V. Johnson, W. R. Raun, and B. R. Simons, Handbook For Soil and Nutrient Management, Deptartement of Plant and Soil Sciences, Oklahoma State University, Stillwater, Okla, USA, 1998.

[32] J. B. Jones Jr. and V. W. Case, "Sampling, handling, and analyzing plant tissue samples," in Soil Testing and Plant Analysis, R. L. Westerman, Ed., SSSA Book Series no. 3, Soil Science Society of America, Madison, Wis, USA, 3rd edition, 1990.

[33] A. Elbert, "Phosphorus: the forgotten, essential ingredient: phosphates enhance the nutritional benefits of foods by adding phosphorus, an essential mineral," 2005, http://www.preparedfoods.com/articles/ingredient-challenges-br-phosphorusthe-forgotten-essential-ingredient.

[34] R. Shapiro and R. P. Heaney, "Co-dependence of calcium and phosphorus for growth and bone development under conditions of varying deficiency," Bone, vol. 32 , no. 5, pp. 532540, 2003.

[35] R. P. Heaney, "Phosphorus nutrition and the treatment of osteoporosis," Mayo Clinic Proceedings, vol. 79, no. 1, pp. 91-97, 2004.

[36] H. J. Harder, R. E. Carlson, and R. H. Shaw, "Corn grain yield and nutrient response to foliar fertilizer applied during grain fill," Agronomy Journal, vol. 74, no. 1, pp. 106-110, 1982.

[37] S. Pellerin, A. Mollier, and D. Plénet, "Phosphorus deficiency affects the rate of emergence and number of maize adventitious nodal roots," Agronomy Journal, vol. 92, no. 4, pp. 690-697, 2000.

[38] W. K. Coblentz, M. B. Daniels, J. L. Gunsaulis et al., "Effects of nitrogen fertilization on phosphorus uptake in bermudagrass forage grown on high soil-test phosphorus sites," Professional Animal Scientist, vol. 20, no. 2, pp. 146-154, 2004.
[39] R. Thiraporn, B. Feil, and P. Stamp, "Effect of nitrogen fertilization on grain yield and accumulation of nitrogen, phosphorus and potassium in the grains of tropical maize," Journal of Agronomy and Crop Science, vol. 169, no. 1-2, pp. 9-16, 1992.

[40] D. Rodríguez, F. H. Andrade, and J. Goudriaan, "Effects of phosphorus nutrition on tiller emergence in wheat," Plant and Soil, vol. 209, no. 2, pp. 283-295, 1999.

[41] C. A. Grant, D. N. Flaten, D. J. Tomasiewicz, and S. C. Sheppard, "The importance of early season phosphorus nutrition," Canadian Journal of Plant Science, vol. 81, no. 2, pp. 211-224, 2001. 


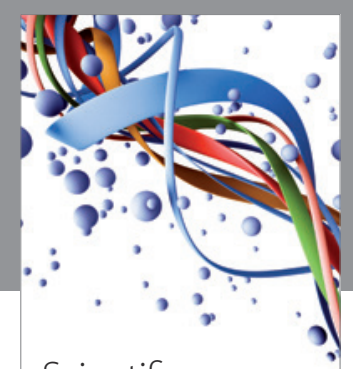

Scientifica
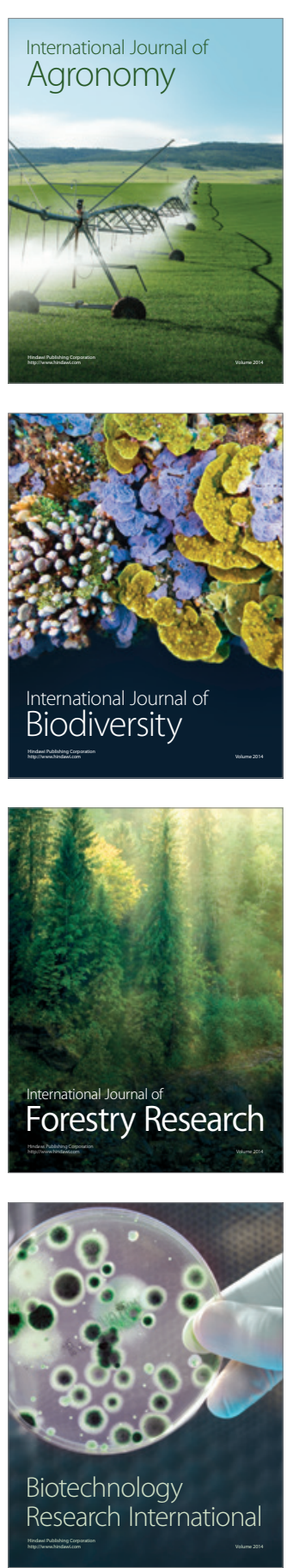
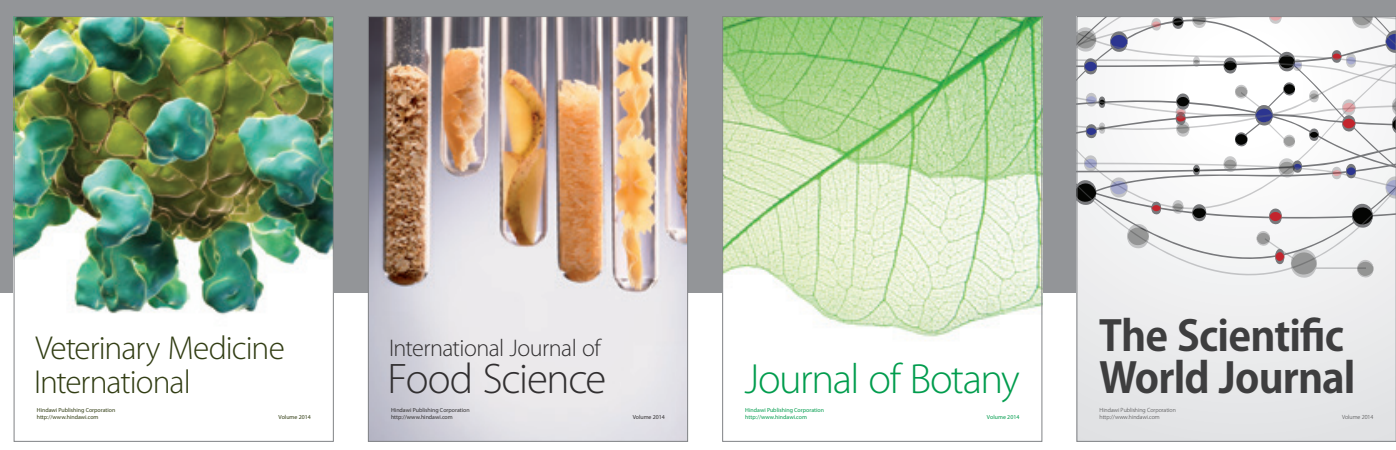

The Scientific World Journal
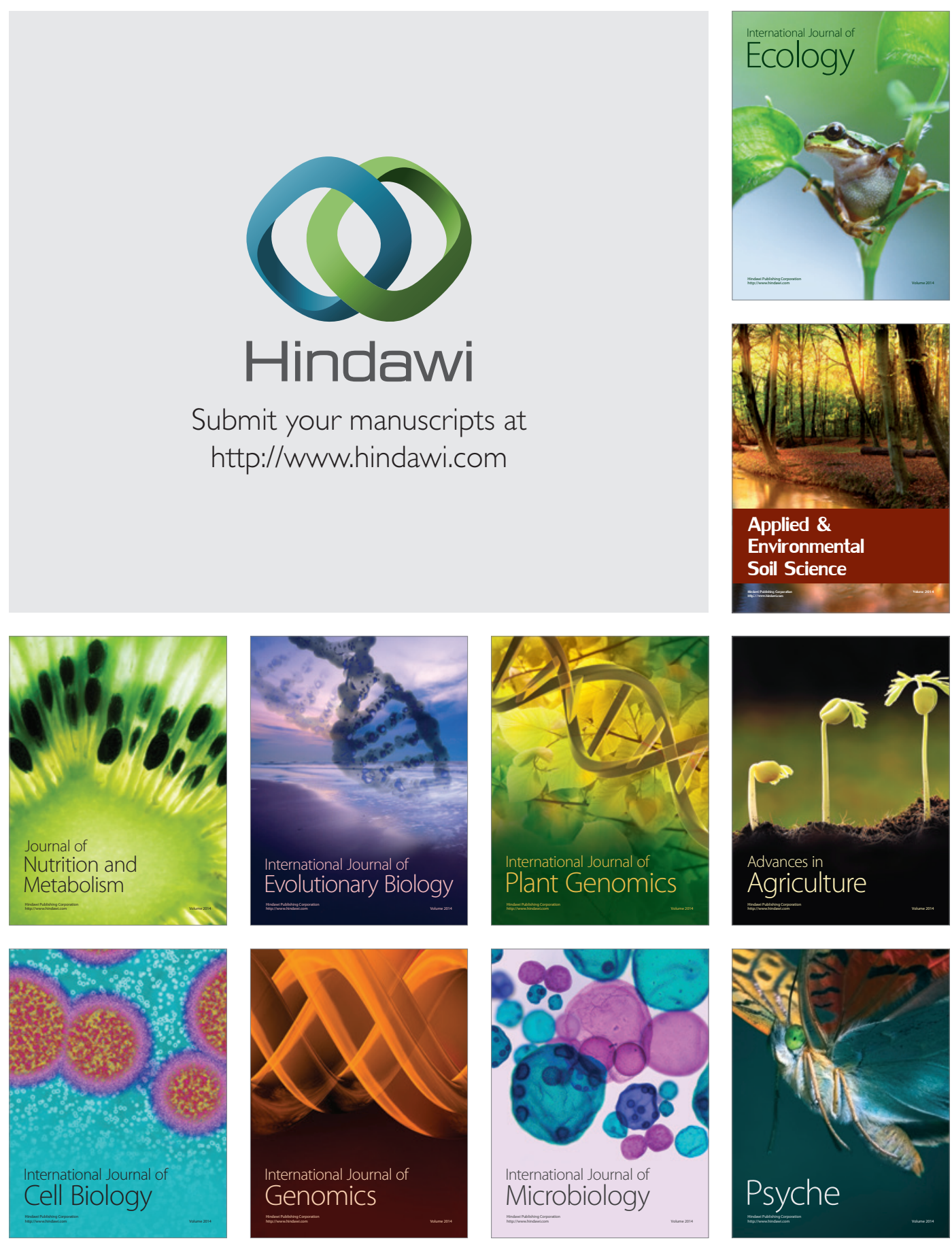